\title{
EDUCATIONAL RESOURCES MANAGERIAL STRATEGY: FINANCIAL MANAGEMENT OF LEGAL EDUCATION BOARD (PERGURUAN TINGGI BADAN HUKUM)
}

\author{
Abdul Azis Wahab ${ }^{a *}$, Dedy Achmad Kurniady ${ }^{\mathrm{b}}$ \\ ${ }^{a * b}$ Educational Administration Programs School of Postgraduate Studies \\ Universitas Pendidikan Indonesia \\ Jl. Dr. setiabudhi No.229. Bandung, Indonesia. ${ }^{a *}$ abdulaziswahab25@gmail.com ${ }^{\text {bdedy achmad@upi.edu }}$
}

\begin{abstract}
The emergence of the era of The Fourth Industrial Revolution (the 4.0 IR), the utilization of education resources optimally and comprehensively has a strategic and significant role in realizing the mission and objectives of higher education that maintains education as its Core Business. In order to be able to manage educational resources effectively and efficiently, appropriate managerial strategies are needed and describe actions based on goals that will be realized so as to create sustainable competitive advantages, in carrying out their programs based on managerial strategies for the use of educational resources efficiently and effectively. This study aims to analyze managerial strategies carried out by universities that have legal entities in using educational resources to support the realization of their mission. The research method used is a case study with a qualitative approach, with the object of research being universities that have legal entities, with the research sample being UPI PTN-BH. The managerial strategy of financial management of all activities is based on internet media (on-line), both in terms of planning, implementation, supervision and reporting. However, it needs to be improved in relation to the competence of the implementing staff in accordance with the needs and demands relating to the applicable financial information technology, in streamlining and streamlining the work patterns that must be applied.
\end{abstract}

Keywords: Educational resources, financial management, Managerial strategies.

Received: 18 June 2018 - Revised: 15 Sep 2019 - Accepted 12 Nov 2019 - Available online 30 Dec 2019

\section{INTRODUCTION}

The optimal and comprehensive use of educational resources has a strategic and significant role in realizing the mission of State Universities that have the status of legal entities (PTN-bh) who maintain education as their Core Business, in accordance with the predetermined mission. In an effort to implement the mission, it requires the ability to establish and implement managerial strategies that are capable of planning and implementing it in the utilization of educational resources efficiently and effectively, especially in the financial sector. The success of a financial field is determined by the extent to which it reaches its intended goals. Achieving these set goals is facilitated by strategic planning and ongoing efforts for improvement (Doost 1999; Nelson, Bailey \& Nelson 1998; Porter 1985). In this way, progress towards achieving success is carried out in a responsible manner so that the mission set by the university can be achieved.

Facing competition between Higher Education institutions in the present and especially in the future which is characterized by increasingly complex global competition, especially with the emergence of the era of The Fourth Industrial Revolution (the 4.0 IR) with all its impacts and opportunities, appropriate managerial strategies and actions are needed. actions based on goals that will be realized, giving rise to a sustainable competitive 
Abdul Azis Wahab et. Al. / Journal of Educational Administration Research and Review /Vol. 2 No.

\section{December 2018}

advantage. Why is that? Because strategy is an overall approach that is related to the implementation of ideas, planning, and execution of an activity in a certain period of time. Organizations can achieve sustainable development when they aspire to meet the needs of the current generation without compromising the ability of future generations in order to meet their needs and aspirations (World Commission for Environment and Development, 1987). In its current efforts, organizations must work in ways that do not endanger the future of social, economic and natural resources (White, 2005).

UPI as a state university has a high degree of autonomy so that it has the ability to utilize education resources that are owned optimally, especially in terms of financial management. With this autonomy, the UPI PTN-BH is expected to be able to obtain and manage existing resources in accordance with the changes that occur, and be able to change the management structure that allows the autonomy to be carried out properly. The UPI PTN-bh with such autonomy has a higher level of accountability and increased efficiency and effectiveness in the utilization of these finances.

In the financial sector, the 2011-2015 UPI Strategic Plan PTN focused on improving the financial system and improving the quality of reports. The target of the strategic plan related to this program is the establishment of a financial system in accordance with applicable regulations, which is in accordance with the status of the university as a PTN-BHU. The implementation of the 2011-2015 UPI RENSTRA shows the improvement in the quality of the UPI planning and budgeting system through the UPI Annual Budget Plan (RKAT) system which is integrated into the eplanning system. In addition, the quality of activity planning and implementation of the financial system also continues to increase through the RKAT monitoring and evaluation system.

The main problems to be examined in this study are related to the implementation of managerial strategies carried out by UPI in utilizing educational resources in the field of financial cultivation, to support the realization of the UPI mission that holds PTN-BH status, while consistently maintaining education as its Core Business. This is a very important focus of study because it is based on the results of secondary data obtained from the UPI Strategic Plan for 2016-2020, which in its implementation there are still some programs that are not in accordance with the expectations set by UPI as PTN-BHU.

Based on this description, the research problem proposed in this study is related to: "How is the managerial strategy implemented by the UPI PTN-bh in the management and utilization of UPI PTN-bh education resources, which includes HR; Finance; and facilities in supporting the realization of the mission carried out by the UPI PTN-BH efficiently and effectively ".

This study aims to describe and analyze the managerial strategies that have been implemented by UPI PTN-BH in using Financial Resources to support the realization of the mission carried out by UPI PTN-BH. The urgency of this research is to overcome the problems of the use of managerial strategies in utilizing Human Resources (HR), Financial Resources, and Facility Resources, to realize the UPI PTN-BH mission efficiently and effectively. Various important steps to overcome these problems must be done. The steps above are an important task for UPI to do, because it involves the credibility of UPI as one of the leading universities in Indonesia that holds PTN-BH status.

\section{METHODS}

This study uses a case study research method. Case studies are research methods that use a variety of data sources that can be used to examine, describe, and explain comprehensively various aspects of individuals, groups of programs, organizations or events systematically. Case studies are suitable research methods when the subject matter of a study relates to "how" and "why", where the focus of research lies in 
Abdul Azis Wahab et. Al. / Journal of Educational Administration Research and Review/Vol. 2 No.

\section{December 2018}

contemporary (present) phenomena in real-life contexts, and researchers have little or no chance opportunity to control events that will be investigated. The unique strength of the case study method is its ability to deal with various types of evidence (multiple sources of evidence), namely documents, tools, interviews, and observations.

The qualitative approach is used as a reason to understand the meaning of the phenomenon of a situation. There are 3 models in qualitative research design, namely descriptive format, ferivicative format and grounded theory format (Bungin Burhan, 2014). Of the three models, researchers used a qualitative descriptive format. This model was chosen because this research includes social science and aims to describe existing phenomena, both natural phenomena and man-made phenomena. This phenomenon can take the form, activity, characteristics, changes, relationships, similarities, and differences between one phenomenon and another.

The choice of qualitative descriptive method of this case study was used to answer the problem formulation in this study, researchers needed multiple sources of data or data from various sources. Case study method is the answer for researchers, because with this method researchers can use a variety of research data sources either by observing activities carried out in the development of college lecturers, conducting interviews with university leaders, and collecting literacy related to the development of lecturers or commonly referred to as documentation.

\section{RESULTS AND DISCUSSION}

College budgets including Higher Education Legal Entities (PTN-bh) such as the University of Education Indonesia, are guided by Strategic Plans that are prepared for a period of five years in accordance with the leadership period and in accordance with the regulations with the applicable mechanism. The Strategic Plan is then described more operationally into the annual budget, called the RKAT. This RKAT is prepared based on certain mechanisms in accordance with the rules and conditions set for each fiscal year nationally and institutionally.

The RKAT that has been submitted by each work unit, to obtain funds from the APBN and RKAT which are funded by Non PNBP, is packaged into one RKAT of the university. This university's RKAT is carried out for the entire program and activities carried out by UPI for each fiscal year. In the current period, financial planning by making RKAT uses eplanning.

Funds allocated in the RKAT UPI for the 2019 and previous fiscal years come from Non PNPB and APBN funds. Non PNBP funds come from the costs of education, cooperation, public funds, and other sources of income. While the state budget funds come from the government, which is calculated to pay salaries and allowances for civil servants and funding assistance for state-owned legal institutions (BPPTNBH) to support higher education operations.

The RKAT preparation starts from an academic unit, namely from the Study Program and Department from each faculty and by the RKAT faculty packaged into a faculty proposal that is submitted to the university level. While the RKAT penysunan in non-academic units in this case is in the form of directives and bureaus in each directorate and bureau consisting of parts and sub-sections and UPTs composing their respective budget proposals which are packaged and delivered to the university level. By the university level the overall proposals in the form of the RKAT are packaged in such a way as to become a university CBTR. This RKAT is funded by two main funding sources, namely funds from the State Budget that are channeled by UPI to the Kemristek Dikti while other funds are sourced from public funds called Non PNBP funds. PTNBH is given full autonomy to manage this Non PNBP fund without having to deposit it to the Ministry of Research and Technology Ministry of Higher Education. 


\section{December 2018}

In accordance with Government Regulation Number 26 Year 2015 and Minister of Finance Regulation Number 139 / PMK.02 / 2015, PTN BH funding can be provided in the form of BH BPPTN and other forms in accordance with laws and regulations. The BPPTN BH funds that have been entered into the BH PTN management account follow the NonPNBP fund management rules. Financial budgeting at the university level is carried out by analyzing 2 things, namely the needs proposed by each unit and the financial condition of the UPI. As for determining the financial condition of UPI every year, namely by calculating UKT (student funds) and BKT (funding assistance from the government). However, the problem is that BKT received by UPI is still low. This is because the achievements of UPI are also still low. Ideally, if the UKT assigned to students is low then the BKT received is expected to be high. However, until now both of them can still be said to be low.

Monitoring is done through an online system. At present, UPI is making a transition to a new system, namely the Billing Information System. The flow is the Officer (Deputy dean / Head of Subdivision of Finance) logged in to check the account, then reports the financial condition through the bookkeeping on the system. The obstacle that arises is that system changes occur in the middle of the year, so the inputted data becomes irrelevant. Ideally, changes will be made at the beginning of the year by conducting coaching and socialization at the end of the previous year.

The current financial reporting carried out by UPI is to use a system similar to a monitoring system, namely the billing information system. So, the data stored from the monitoring results will be accumulated to be quarterly and year-end reports. Besides that, the reporting system built adheres to the principle of transparency and accountability of UPI.

Financial reporting is done through the submission of reports to a system implemented by UPI. At present, the reporting system used by UPI is SINTA. In addition, transparency in terms of university financial reporting was also carried out during the Meeting which was attended by leaders who were authorized up to the head of the study program in each faculty. The policy is the embodiment of the mission that has been set in the implementation of higher education.

The main mission of Higher Education is to seek, discover, disseminate and uphold the truth. In order for this mission to be realized, Universities as organizers of Higher Education must be free from any influence, pressure and contamination such as political power and/or economic power, so that the Tridharma of Higher Education, namely education, research, or community service, can be implemented based on academic freedom and scientific autonomy. Therefore, naturally Universities have autonomy or independence, both academically and nonacademically.

If the autonomy of Higher Education is the nature of higher education, the State is responsible for protecting and guaranteeing that nature through the stipulation of various laws and regulations, including Government Regulation on the Form and Funding Mechanism of Legal Entity Universities.

The Government Regulation on the Form and Mechanism of Higher Education Institutions is a mandate of Article 89 paragraph (3) of Law Number 12 of 2012 concerning Higher Education, which states that the provisions regarding the form and mechanism of Funding in Legal Entity PTNs are regulated by Government Regulation.

One concrete effort to realize transparency and accountability in managing state finances is the submission of government financial accountability reports that meet the principles on time and are prepared in accordance with government accounting standards that have been generally accepted.

The managerial strategy currently implemented by UPI in terms of management planning relating to the distribution and 
Abdul Azis Wahab et. Al. / Journal of Educational Administration Research and Review/Vol. 2 No.

\section{December 2018}

allocation of funds that must be channeled has referred to the national regulations and policies of the UPI itself.

The sources of funding obtained by UPI as an institution that already holds PTN-BH status, where the acquisition of the required funding sources, is in accordance with the rules. However, the funds obtained need clarity and transparency in their use both at the level of Department / Study Program, Faculty, and other units within the UPI, in terms of programs or activities that need to be funded along with the amount to be distributed in accordance with the mission and the stated objectives, whether sourced from the government, the community, and the results of the independent business carried out by UPI

In terms of financial management carried out by UPI, all activities have been based on internet media (on-line), both in terms of planning, implementation, supervision and reporting. However, it needs to be improved in relation to the competence of the implementing staff in accordance with the needs and demands relating to the applicable financial information technology, in streamlining and streamlining the work patterns that must be applied.

In addition, building a work culture based on achieving institutional goals is a concern for every leader. This will provide positive energy for all members of the organization in carrying out their roles and responsibilities. It is also a concern for every leader, that cultural changes, needs, and scientific developments that are felt so quickly in achieving the goals of the institution, can be anticipated quickly. Therefore the development of the capacity and competency of every employee in the UPI environment is another priority focus. Performance measurement is very important in this process. It shows direction and provides feedback about the effectiveness of planning, implementing plans, achieving goals and efforts to increase productivity. (

In relation to the development of demands and needs that are felt to be always increasing and changing, related to the operational policies of organizations in the UPI environment, which require the achievement of performance and productivity efficiently and effectively, UPI made breakthroughs in the development of financial / accounting information systems. However, this needs to be accompanied by the suitability of the capabilities or competencies that each employee needs in the relevant unit environment, especially in the financial sector, and changes that occur often occur when the previous system is in progress, so that the changes are less able to be followed by all UPI employees, especially the finance department.

Besides that, in carrying out UPI's financial management, there was a lack of coordination between the parties involved, including the finance directorate, planning and development and the ICT patronage because the parties involved were under different commands. Another obstacle is in technical improvements in financial administration that are implemented in a system that has not been tested but the decision has been implemented.

\section{CONCLUSION/RECOMENDATION}

Managerial strategies in the financial field of UPI, especially personnel who have the duty as financial operators, need to improve their competencies and knowledge, which are related to financial information systems or accounting sciences in order to support the creation of financial reporting systems that are appropriate and established by UPI.

The development of a financial information system that has been carried out by UPI needs to be clearly informed and there is socialization before the system is implemented at each level or work unit within the UPI.

Training related to the development and implementation of the financial system needs to be carried out periodically and continuously in order to improve the competencies / abilities that must be possessed by every employee in the financial sector, and other units that have financial responsibility and 
Abdul Azis Wahab et. Al. /Journal of Educational Administration Research and Review /Vol. 2 No. 2 December 2018

management roles in the UPI environment. , so that they are able to face various challenges and obstacles that occur in financial management and reporting activities.

The managerial strategy undertaken by UPI for future programs is focused on efforts to build a quality work culture based on the need for efficient and effective financial system implementation. For the achievement of the established UPI mission, by implementing information technology advances.

\section{REFERENCES}

Bungin, Burhan. 2014. Penelitian Kualitatif . Jakarta : Kencana Prenada Media

Djam'an S., \& Aan Komariah (2010). Metodologi Penelitian Kualitatif. Alfabeta, Bandung

Doost, R.K. 1999. The missing links in Accounting Education, Managerial Auditing Journal, Vol. 14. No. 3, pp.93-114.

FNS Vermaak, \& CJ Cronjé (2001).The balanced scorecard as a potential instrument for supporting the planning and improvement of accounting education in South Africa, Meditari Accountancy Research Vol. 9 2001: 301-312

Nelson, I.T., Bailey, J.A. and Nelson, A.T. 1998. Changing accounting education with purpose: Market-based strategic planning for departments of accounting, Issues in Accounting Education, Vol. 13, No. 2, pp.301-326.

Peraturan Pemerintah Nomor 26 Tahun 2015 tentang Bentuk Dan Mekanisme Pendanaan Perguruan Tinggi Negeri Badan Hukum

Peraturan Menteri Keuangan RI Nomor 139/PMK.02/2015 tentang Tata Cara Penyediaan, dan Pertanggungjwaban Pemberian Bantuan Pendanaan Perguruan Tinggi Badan Hukum.

Porter, M.E. 1985. Competitive Advantage: Creating and Sustaining Superior Performance, The Free Press, New York.

White GB (2005). How to report a companyes sustainability activities. Manage. Account., 7(1): 36-43.

World Commission on Environment and Development - WCED (1987). Our common future. Oxford: Oxford University Press. [Online] Available from:

http://www.wsu.edu/ susdev/WCED87.html [Accessed: 2018-12-16]. 